\title{
Age, Sex, and Seasonal Variations in the Serum Vitamin D3 Levels in a Local Turkish Population
}

\author{
Sinem BOZKURT, ${ }^{1}$ Berat Meryem ALKAN, ${ }^{1}$ Fatma YILDIZ, ${ }^{1}$ Sevgi GÜMÜŞ, ${ }^{1}$ \\ Nebahat SEZER, ${ }^{2}$ Özge ARDIÇOĞLU, ${ }^{1}$ Selami AKKUŞ² \\ ${ }^{1}$ Department of Physical Medicine and Rehabilitation, Atatürk Training and Research Hospital, Ankara, Turkey \\ ${ }^{2}$ Department of Physical Medicine and Rehabilitation, Medical Faculty of Yıldırım Beyazıt University, Ankara, Turkey
}

\begin{abstract}
Objectives: This study aims to assess the 25-hydroxyvitamin $\mathrm{D}[25-(\mathrm{OH}) \mathrm{D}]$ levels in patients who were seen at a physical medicine and rehabilitation outpatient clinic while also taking into account the seasonal serum vitamin D (vit D) variation.

Patients and methods: We retrospectively evaluated the medical records of the patients who attended a physical medicine and rehabilitation outpatient clinic, and the serum $25-(\mathrm{OH}) \mathrm{D}$ levels in 440 subjects of varying ages and sexes in both the summer $(n=177)$ and winter $(n=263)$. Serum 25-(OH)D, parathyroid hormone, alkaline phosphatase (ALP), calcium, and phosphorus levels were recorded.

Results: A large percentage of the adult Turkish population has insufficient levels of vit $\mathrm{D}$ during the winter and summer. Serum $25-(\mathrm{OH}) \mathrm{D}$ levels were significantly lower in the winter compared with the summer season (mean vit D: $13.9 \mu / \mathrm{l}$ and $19.7 \mu / \mathrm{l}$, respectively; $\mathrm{p} \leq 0.001)$. The prevalence of $25-(\mathrm{OH}) \mathrm{D}$ deficiency was $94 \%$ in the winter and $85 \%$ in the summer. With respect to age or sex, there were no differences in the $25-(\mathrm{OH}) \mathrm{D}$ levels.

Conclusion: Our results indicate that although Turkey is a Mediterranean country, the Turkish people should check have their levels of $25-(\mathrm{OH}) \mathrm{D}$ periodically checked, and if necessary, appropriate supplements should be given to prevent a secondary chronic disease due to vit $D$ deficiency.

Keywords: 25-hydroxyvitamin D defficiency; seasonal variations; vitamin D.
\end{abstract}

Vitamin D (vit D) plays an important role in mineral calcium and phosphate homeostasis, cell differentiation, the regulation of parathyroid hormone (PTH) inhibition, T-cell suppression and macrophage deregulation, cancer pathogenesis, and erythropoiesis. ${ }^{1,2}$ Low levels of 25-Hydroxyvitamin D [25- $(\mathrm{OH}) \mathrm{D}]$ result in increased amounts of $\mathrm{PTH}$, which is all too often followed by a bone mineralization defect (osteomalacia) and bone loss (osteoporosis). ${ }^{3}$

Sources of vit D are sunlight, food, and supplements, with sunlight being the predominant source. In the United Kingdom (UK), 30 minutes of sunlight on the face and forearms at midday from April to October will generate 2000 IU of vit $\mathrm{D}$ per day in fair-skinned individuals. ${ }^{4} \mathrm{~A}$ recent study conducted on 7,437 British Caucasians born in 1958 showed that $47 \%$ of British adults have insufficient levels of serum 25-(OH)D $(<40 \mathrm{nmol} / \mathrm{l})$ and $16 \%$ have deficient levels $(<25 \mathrm{nmol} / \mathrm{l})$ in the winter and spring. ${ }^{5}$ Furthermore, a study from Canada showed that the prevalence of vit $\mathrm{D}$ insufficiency was generally lowest in the summer and highest in the fall and winter, with $20 \%$ of the participants having 25-(OH)D concentrations below $40 \mathrm{nmol} / 1$ during the winter. ${ }^{6}$ Pigmented skin, sun 
creams with a protection factor of 15 or more, and the poor winter sun in the UK all lead to lower levels of vit $\mathrm{D}$ synthesis in the skin. ${ }^{7}$ Furthermore, clothing that hides the face and forearms also increases the risk of vit $\mathrm{D}$ deficiency.

Among the elderly, vit $\mathrm{D}$ deficiency is particularly common, but this varies widely among different countries. ${ }^{8}$ Elderly populations living in residential homes and nursing homes have plasma $25-(\mathrm{OH}) \mathrm{D}$ levels of $9-37 \mathrm{nmol} / \mathrm{l}$ in Europe compared with $53-45 \mathrm{nmol} / \mathrm{l}$ in the USA and 26-40 nmol/1 in Australia. ${ }^{9}$ In addition, 25-(OH) $\mathrm{D}$ levels in all geriatric patients are lower in European countries $(3.3-29 \mathrm{nmol} / \mathrm{l})$ than in the USA (45-71 nmol/l). ${ }^{9}$

Vitamin $\mathrm{D}$ status is readily assessed by measuring the serum $25-(\mathrm{OH}) \mathrm{D}$, with most authorities defining optimal, adequate, deficient, and insufficient levels as $>75 \mathrm{nmol} / \mathrm{l}(>30 \mu \mathrm{g} / \mathrm{l}), \quad 50-75 \mathrm{nmol} / \mathrm{l}$ $(=20-30 \mu \mathrm{g} / \mathrm{l}), 25-49 \mathrm{nmol} / \mathrm{l}(=10-19 \mu \mathrm{g} / \mathrm{l})$, and $<25 \mathrm{nmol} / \mathrm{l} \quad(<10 \mu \mathrm{g} / \mathrm{l})$, respectively. ${ }^{4}$ Common causes of vit $\mathrm{D}$ deficiency include diets which are low in this essential vitamin and reduced exposure to sunlight. Our city (Ankara) is located between 39-56 north latitude (parallels) and 32-52 east longitude and gets ample sunshine, with an average of over 10 hours a day in summer and three hours a day in winter..$^{10}$ Our primary objective was to determine the vit $\mathrm{D}$ status among a healthy population of varying ages and genders while also taking into account seasonal variations between summer and winter.

\section{PATIENTS AND METHODS}

In this retrospective study, we evaluated the medical records of the patients who came to our physical medicine and rehabilitation outpatient clinic that we suspected were deficient in vit $\mathrm{D}$ because of their medical history and physical examination results. Since the data was stored in our database, this permitted us to identify the ages, genders, and dates for all of the requested patients. We then recorded all of the serum 25-(OH)D measurements over the four-month periods from June $1^{\text {st }}, 2011$ to October $1^{\text {st }}, 2011$ and from December $1^{\text {st }}, 2011$ to April $1^{\text {st }}, 2012$. The Chromsystems high-pressure liquid chromatography (HPLC) vitamin D2/D3 kit
(Chromsystems Instruments and Chemicals $\mathrm{GmbH}$, Gräfelfing, Munich, Germany) was used to measure the serum $25-(\mathrm{OH}) \mathrm{D}$ levels of the patients, and they were then divided into the following three groups: those with adequate serum levels of $\geq 30 \mu \mathrm{g} / \mathrm{l}$ (group 1), those with deficient levels of $12-30 \mu \mathrm{g} / \mathrm{l}$ (group 2), and those with insufficient levels of $<12 \mu \mathrm{g} / 1$ (group 3). Additionally, the serum levels of alkaline phosphatase (ALP), calcium, and phosphorus were also recorded. Afterwards, the patients were then classified according to age (group $1=<40$, group $2=40-60$, group $3=>60$ ), gender, and season (winter-summer groups).

Those who were pregnant or breastfeeding at the time of study, those with significant renal, hepatic, or thyroid dysfunctions, or those suffering from other major systemic diseases such as malignancy, diabetes mellitus (DM), and metabolic bone diseases were excluded from the study.

The data was analyzed using the SPSS Statistics version 17.0.1 for Windows (SPSS Inc., Chicago, IL, USA). Group sample sizes of 262 (winter group) and 173 (summer group) were used in order to achieve $100 \%$ power to detect a difference of 5.9 between the null hypothesis, which stated that both group means were 19.8, and the alternative hypothesis, which indicated that the mean of group 2 was 13.9 with known group standard deviations (SDs) of 13.9 and 8.6 and a significance level (alpha) of 0.05 using a two-sided, two-sample t-test. In addition, descriptive statistics were used to describe the demographic characteristics of the patients. Normally distributed data was compared using either Student's t-test or analysis of variance (ANOVA) while nonparametric data was compared utilizing the Mann-Whitney U test or Kruskal-Wallis test. Comparative analyses of the demographic characteristics with respect to gender were also computed using the Mann-Whitney U test, whereas comparative analyses of the demographic characteristics and mean group scores among the summer and winter groups were calculated using Student's t-test. Furthermore, the age groups were compared using the Kruskal-Wallis test, and a post hoc analysis was conducted using the MannWhitney U test. Spearman's correlation tests were also used to determine the relationships between the variables, and the level of significance was set at $\mathrm{p}<0.05$. 


\begin{tabular}{|c|c|c|c|c|c|}
\hline Characteristics & $\mathrm{n}$ & $\%$ & Mean \pm SD & Median & Min.-Max. \\
\hline Age (years) & & & $48.7 \pm 14.2$ & 49.0 & $20-87$ \\
\hline \multicolumn{6}{|l|}{ Gender } \\
\hline Male & 37 & 8.5 & & & \\
\hline Female & 398 & 91.5 & & & \\
\hline 25-hydroxyvitamin $\mathrm{D}(\mu \mathrm{g} / \mathrm{l})$ & & & $16.3 \pm 11.0$ & 12.5 & $5.3-84$ \\
\hline Calcium (mg/dl) & & & $9.5 \pm 0.5$ & 9.5 & $7.8-10.5$ \\
\hline Phosphorus (mg/dl) & & & $3.5 \pm 0.6$ & 3.5 & $2.30-5.40$ \\
\hline Alkaline phosphatase (U/l) & & & $75.1 \pm 25.2$ & 71.0 & $32-185$ \\
\hline Parathyroid hormone (pg/ml) & & & $57.5 \pm 33.8$ & 48.4 & $13.7-270$ \\
\hline
\end{tabular}

\section{RESULTS}

In this study, we analyzed 435 samples (262 winter samples and 173 summer samples). The patients ranged between 20 and 87 years of age (mean $48.72 \pm 14.22)$, and the mean $25-(\mathrm{OH}) \mathrm{D}$ status was $16.25 \pm 10.98 \mu / 1$. The serum calcium was measured, and the median adjusted calcium was $9.47 \mathrm{mg} / \mathrm{dl}$ (range $7.8-10.5 \mathrm{mg} / \mathrm{dl}$ ). The characteristics of our samples are shown in Table 1.

Most of the participants in our study were women (91\%), but we found that they [25-(OH)D: 12.9] were not more likely to have $25-(\mathrm{OH}) \mathrm{D}$ deficiency than men [25-(OH)D: 14.7] in our survey. In fact, we determined that the only statistically significant difference ( $p=0.008$ ) with regard to gender involved the PTH levels. All of the characteristics of the participants with respect to gender are summarized in Table 2.

We also found that there was a statistically significant difference in the $25-(\mathrm{OH}) \mathrm{D}$ and ALP levels between the seasonal groups. However, the PTH levels were not significantly higher $(54 \pm 32 \mathrm{pg} / \mathrm{mL})$ in the winter compared with the summer $(52.5 \pm 31.5 \mathrm{pg} / \mathrm{mL})$. In addition, there was a weak but significant negative correlation between 25- $(\mathrm{OH}) \mathrm{D}$ and PTH $(\mathrm{r}=-0.26, \mathrm{p}<0.001)$, but only $23 \%$ of the participants had secondary hyperparathyroidism (PTH $>67 \mathrm{pg} / \mathrm{mL}$; hospital standardized laboratory reference range: 12-67). A comparison of the mean scores of the characteristics of the study population with respect to season are given in Table 3. The proportion of patients with 25- $(\mathrm{OH}) \mathrm{D}$ deficiency showed seasonal variations, with $90.8 \%(\mathrm{n}=395)$ having insufficient levels of vit $\mathrm{D}$ in both the winter and summer. Moreover, 25-(OH)D insufficiency was found in 94\% of the cases in the winter and $85 \%$ in the summer $(\mathrm{p}<0.001)$.

However, we detected no significant differences in the levels of $25-(\mathrm{OH}) \mathrm{D}$ between the age groups. Table 4 gives a comparison of the mean scores of characteristics of the study population with respect to age.

\section{DISCUSSION}

Calcium and bone metabolism are heavily influenced by $25-(\mathrm{OH}) \mathrm{D}$, which increases the intestinal absorption of calcium and phosphate and is an essential factor in skeletal mineralization. Furthermore, 25- $(\mathrm{OH}) \mathrm{D}$ seems to play an important

Table 2. The characteristics of the study population with respect to gender

\begin{tabular}{|c|c|c|c|c|c|c|c|}
\hline \multirow[b]{2}{*}{ Characteristic } & \multicolumn{3}{|c|}{$\operatorname{Men}(n=37)$} & \multicolumn{3}{|c|}{ Women $(n=398)$} & \multirow[b]{2}{*}{$p$} \\
\hline & Mean \pm SD & Median & Min.-Max. & Mean \pm SD & Median & Min.-Max. & \\
\hline Age (years) & & 44 & $24-78$ & & 49 & $20-87$ & 0.217 \\
\hline 25-hydroxyvitamin D ( $\mu \mathrm{g} / \mathrm{l})$ & & 14.70 & $6.6-40.5$ & & 12.95 & $5.3-84$ & 0.060 \\
\hline Calcium (mg/dl) & $9.5 \pm 0.4$ & & $9-10$ & $9.5 \pm 0.5$ & & $8-10.5$ & 0.545 \\
\hline Phosphorus (mg/dl) & $3.4 \pm 0.5$ & & $2.5-4.2$ & $3.6 \pm 0.5$ & & $2.3-5.4$ & 0.215 \\
\hline Alkaline phosphatase (U/l) & & 78 & $47-143$ & & 70.5 & $32-185$ & 0.195 \\
\hline Parathyroid hormone $(\mathrm{pg} / \mathrm{ml})$ & & 40.65 & $14.8-78.8$ & & 49.8 & $13.7-270$ & $0.008^{*}$ \\
\hline
\end{tabular}


Table 3 . The characteristics of the study population with respect to season

\begin{tabular}{|c|c|c|c|c|c|}
\hline \multirow[b]{2}{*}{ Characteristic } & \multicolumn{2}{|c|}{ Summer group ( $n=173$ ) } & \multicolumn{2}{|c|}{ Winter group $(\mathrm{n}=262)$} & \multirow[b]{2}{*}{$p$} \\
\hline & Mean \pm SD & Min.-Max. & Mean \pm SD & Min.-Max. & \\
\hline Age (years) & $45.0 \pm 14.3$ & $20-82$ & $51.1 \pm 13.6$ & $20-87$ & $<0.001^{*}$ \\
\hline 25-hydroxyvitamin D ( $\mu \mathrm{g} / \mathrm{l})$ & $19.8 \pm 13.9$ & $5.3-84$ & $13.9 \pm 8.6$ & $7-69.3$ & $<0.001^{*}$ \\
\hline Calcium (mg/dl) & $9.6 \pm 0.6$ & $7.8-10.5$ & $9.6 \pm 0.5$ & $8.4-10.5$ & 0.786 \\
\hline Phosphorus (mg/dl) & $3.6 \pm 0.5$ & $2.4-5$ & $3.6 \pm 0.5$ & $2.3-5.4$ & 0.612 \\
\hline Alkaline phosphatase (U/l) & $67.8 \pm 26.6$ & $32-185$ & $79 . \pm 23.7$ & 34-154 & $<0.001^{*}$ \\
\hline Parathyroid hormone $(\mathrm{pg} / \mathrm{ml})$ & $52.7 \pm 31.5$ & $18.4-270$ & $54.2 \pm 32.1$ & $13.7-270$ & 0.62 \\
\hline
\end{tabular}

part in the preservation of neuromuscular functions and the prevention of certain cancers. ${ }^{11}$ Less severe $25-(\mathrm{OH}) \mathrm{D}$ deficiency appears to be quite common, especially among the elderly.

In Europe, 25- $(\mathrm{OH}) \mathrm{D}$ deficiency is very common. ${ }^{8}$ However, seasonal variations in 25- $(\mathrm{OH}) \mathrm{D}$ concentrations have a substantial effect on the diagnosis of 25-(OH)D insufficiency because cholecalciferol is synthesized in the skin under the impact of ultraviolet (UV) light. ${ }^{12}$ During the winter at northern latitudes, sunlight has to go a much longer distance through the atmosphere, and most of the UV light is absorbed on the journey. ${ }^{8}$ Therefore, there is almost no $25-(\mathrm{OH}) \mathrm{D}$ production between October and March in the northern part of the United States and Canada or in northwestern Europe,$^{13}$ but this is usually not the case in countries located more to the south. ${ }^{8}$ A large French study reported that $14 \%$ of healthy adults suffered from $25-(\mathrm{OH}) \mathrm{D}$ deficiency during the wintertime, ${ }^{14}$ and Levis et al. ${ }^{11}$ in a study that focused on a South Florida population found that seasonal variations were responsible for a $14 \%$ increase in $25-(\mathrm{OH}) \mathrm{D}$ concentrations in men and $13 \%$ in women during the summer, both of which were statistically significant. ${ }^{11}$ Moreover, Bolland et al. ${ }^{15}$ showed a much higher prevalence of $25-(\mathrm{OH}) \mathrm{D}$ concentrations $<50 \mathrm{nmol} / \mathrm{L}$ (73\% in women and $39 \%$ in men) in the late winter and early spring in New Zealand. The first main finding of our survey of serum $25-(\mathrm{OH}) \mathrm{D}$ in Turkey was that the 25-(OH)D levels differed significantly between seasonal groups, with the levels of $25-(\mathrm{OH}) \mathrm{D}$ being lower in the winter than the summer. Additionally, we determined that $90.8 \%$ of the patients had insufficient levels of $25-(\mathrm{OH}) \mathrm{D}$ in both the winter and the summer, and we found $25-(\mathrm{OH}) \mathrm{D}$ insufficiency in $94 \%$ of the cases in the winter and $85 \%$ in the summer $(p<0.001)$.

The differences in the mean $25-(\mathrm{OH}) \mathrm{D}$ levels between the genders in our study were not statistically significant $(p=0.06)$. Similarly, Kashi et al. ${ }^{16}$ showed that both genders had 25- $(\mathrm{OH}) \mathrm{D}$ deficiency in the summer and winter. On the other hand, a study by Ono et al. ${ }^{17}$ showed that the serum $25-(\mathrm{OH}) \mathrm{D}$ levels were higher in men than in women, but these differences could be related to how much skin was covered as well as their jobs.

The majority of elderly patients in the United States and Europe have 25-(OH)D insufficiency. ${ }^{2,18,19}$ Perhaps this is because they do not often go outside in the sunshine. In addition, vit D3 formation in the skin is much more efficient in younger people. ${ }^{20,21}$ Our data indicated that $25-(\mathrm{OH}) \mathrm{D}$ levels did not differ statistically with respect to age $(p=0.396)$. Reginster et al. ${ }^{22}$ showed that PTH levels rose in conjunction with increased age,

Table 4. Comparison of the characteristics of the study population with respect to age groups

\begin{tabular}{|c|c|c|c|c|c|c|c|}
\hline \multirow[t]{2}{*}{ Characteristic } & \multicolumn{2}{|c|}{ Group 1 ( $\mathrm{n}=142)$} & \multicolumn{2}{|c|}{ Group 2 (n=185) } & \multicolumn{2}{|c|}{ Group 3 (n=108) } & \multirow[b]{2}{*}{$p$} \\
\hline & Mean \pm SD & Min.-Max. & Mean \pm SD & Min.-Max. & Mean \pm SD & Min.-Max. & \\
\hline Age (years) & $34.0 \pm 5.8$ & $20-40$ & $50.0 \pm 4.3$ & $41-60$ & $67.0 \pm 6.5$ & $61-87$ & $<0.001^{*}$ \\
\hline 25-hydroxyvitamin D ( $\mu \mathrm{g} / \mathrm{l})$ & $13.5 \pm 1$ & $5.85-72.4$ & $12.2 \pm 10.4$ & $6.4-69.3$ & $11.8 \pm 10.4$ & $5.3-84$ & 0.610 \\
\hline Calcium (mg/dl) & $9.5 \pm 0.5$ & 8.4-10.9 & $9.7 \pm 0.4$ & 8.3-10.9 & $9.7 \pm 0.5$ & 7.8-11 & 0.474 \\
\hline Phosphorus (mg/dl) & $3.6 \pm 0.5$ & $2.4-5.3$ & $3.7 \pm 0.5$ & $2.30-5.0$ & $3.8 \pm 0.5$ & $2.5-5.4$ & 0.179 \\
\hline Alkaline phosphatase (U/l) & $62.0 \pm 19.6$ & $34-143^{* *}$ & $73.0 \pm 23.7$ & $34-146$ & $80.0 \pm 28.9$ & $32-185$ & $<0.001^{*}$ \\
\hline Parathyroid hormone (pg/ml) & $43.9 \pm 22.4$ & $14.3-107.3$ & $48.1 \pm 25.6$ & $18-167$ & $45.5 \pm 49.7$ & $13.7-270$ & 0.198 \\
\hline
\end{tabular}


and this stratified according to decreased levels of 25-(OH)D. Moreover, Haden et al. ${ }^{23}$ suggested that the level of PTH secretion should be higher in the elderly because of serum calcium changes that were independent of vitamin status or renal functions. However, in this study, there were no statistically significant differences in the PTH levels between the age groups, and the levels were statistically lower in the male participants. One possible explanation for this might be that the $25-(\mathrm{OH}) \mathrm{D}$ levels of the females were lower than for the males, but whatever the cause, the difference was not statistically significant.

Lower serum 25-(OH)D concentrations lead to lower calcium absorption, and lower serum calcium concentrations cause an increase in PTH secretion. While this study confirmed the high prevalence of $25-(\mathrm{OH}) \mathrm{D}$ defficiency in our patients, secondary hyperparathyroidism was present in only $23 \%$ of the participants. In a study conducted on an Indo-Asian population by Serhan et al., ${ }^{24}$ the prevalence of $25-(\mathrm{OH}) \mathrm{D}$ defficiency was $58 \%$, and only $30 \%$ of the participants had secondary hyperparathyroidism. Similarly, Sahota et al. ${ }^{25}$ reported that $25-(\mathrm{OH}) \mathrm{D}$ defficiency was prevalent in $39 \%$ of the participants in their study, and only $33 \%$ had secondary hyperparathyroidism. Our study also determined that the PTH levels differed significantly between the genders, but this was not related to the seasons. In addition, Chapuy et al. ${ }^{14}$ reported that $14 \%$ of the healthy adults in their study suffered from 25-(OH)D deficiency during the wintertime, and this was often accompanied by elevated PTH levels.

Our study had some limitations. First of all, it was a retrospective study, so we had no knowledge of the patients' body mass index, degree of sun exposure, or vit $\mathrm{D}$ intake. A high body mass index is proportional to lower $25-(\mathrm{OH}) \mathrm{D}$ values, and this is possibly due to the lipid-soluble vit $\mathrm{D}$ stored in fat tissues that causes a reduction in serum levels. ${ }^{3,26}$ Another limitation of this study was that we compared the vit $\mathrm{D}$ values with respect to gender even though the majority of the participants were women (91\%).

One problem with studies of this type is that there is no consensus on the optimal levels of serum $25-(\mathrm{OH}) \mathrm{D} .{ }^{27,28}$ Another issue involves the variations in the reference populations in which vit $\mathrm{D}$ levels have been studied since it has been stated that studies based on vit $\mathrm{D}$ levels of healthy people are more reliable. ${ }^{8}$

In summary, our findings showed that even in sunny environments, $25-(\mathrm{OH}) \mathrm{D}$ deficiency is quite common, and the prevalence rate is high even in the summer. The good news is that vit D insufficiency can be easily overcome by encouraging an increased intake.

\section{Conclusion}

Although Turkey is a Mediterranean country, Turkish people should have their levels of 25- $(\mathrm{OH}) \mathrm{D}$ checked at periodic intervals throughout their lives. Furthermore, proper supplementation should be considered to avoid a secondary chronic disorder that may arise from $25-(\mathrm{OH}) \mathrm{D}$ deficiency.

\section{Declaration of conflicting interests}

The authors declared no conflicts of interest with respect to the authorship and/or publication of this article.

\section{Funding}

The authors received no financial support for the research and/or authorship of this article.

\section{REFERENCES}

1. Smith M. Seasonal, ethnic and gender variations in serum vitamin D3 levels in the local population of Peterborough. Bioscience Horizons 2010;3:124-31.

2. Tangpricha V, Pearce EN, Chen TC, Holick MF. Vitamin $\mathrm{D}$ insufficiency among free-living healthy young adults. Am J Med 2002;112:659-62.

3. Erkal MZ, Wilde J, Bilgin Y, Akinci A, Demir E, Bödeker $\mathrm{RH}$, et al. High prevalence of vitamin D deficiency, secondary hyperparathyroidism and generalized bone pain in Turkish immigrants in Germany: identification of risk factors. Osteoporos Int 2006;17:1133-40.

4. Pearce SH, Cheetham TD. Diagnosis and management of vitamin D deficiency. BMJ 2010;340:b5664.

5. Hyppönen E, Power C. Hypovitaminosis D in British adults at age $45 \mathrm{y}$ : nationwide cohort study of dietary and lifestyle predictors. Am J Clin Nutr 2007;85:860-8.

6. Rucker D, Allan JA, Fick GH, Hanley DA. Vitamin $\mathrm{D}$ insufficiency in a population of healthy western Canadians. CMAJ 2002;166:1517-24.

7. Rosen CJ. Clinical practice. Vitamin D insufficiency. N Engl J Med 2011;364:248-54.

8. Lips P. Vitamin D deficiency and secondary hyperparathyroidism in the elderly: consequences for bone loss and fractures and therapeutic implications. Endocr Rev 2001;22:477-501. 
9. Mosekilde L. Vitamin D and the elderly. Clin Endocrinol (Oxf) 2005;62:265-81.

10. Available from: http://www.mgm.gov.tr/ veridegerlendirme/il-ve-ilceler-istatistik.aspx

11. Levis S, Gomez A, Jimenez C, Veras L, Ma F, Lai S, et al. Vitamin d deficiency and seasonal variation in an adult South Florida population. J Clin Endocrinol Metab 2005;90:1557-62.

12. Holick MF. Vitamin D and the skin: photobiology, physiology and therapeutic efficacy for psoriasis. In: Heersche J, Kanis J, editors. Bone and Mineral Research. Amsterdam: Elsevier; 1990. p. 313-66.

13. Webb AR, Kline L, Holick MF. Influence of season and latitude on the cutaneous synthesis of vitamin D3: exposure to winter sunlight in Boston and Edmonton will not promote vitamin D3 synthesis in human skin. J Clin Endocrinol Metab 1988;67:373-8.

14. Chapuy MC, Preziosi P, Maamer M, Arnaud S, Galan P, Hercberg S, et al. Prevalence of vitamin D insufficiency in an adult normal population. Osteoporos Int 1997;7:439-43.

15. Bolland MJ, Grey AB, Ames RW, Mason BH, Horne AM, Gamble GD, Reid IR. The effects of seasonal variation of 25-hydroxyvitamin $\mathrm{D}$ and fat mass on a diagnosis of vitamin D sufficiency. Am $\mathrm{J}$ Clin Nutr 2007;86:959-64.

16. Kashi Z, Saeedian Fs, Akha O, Gorgi Ma, Emadi Sf, Zakeri H. Vitamin D deficiency prevalence in summer compared to winter in a city with high humidity and a sultry climate. Endokrynol Pol 2011;62:249-51.

17. Ono Y, Suzuki A, Kotake M, Zhang X, NishiwakiYasuda K, Ishiwata Y, et al. Seasonal changes of serum 25-hydroxyvitamin $\mathrm{D}$ and intact parathyroid hormone levels in a normal Japanese population. J Bone Miner Metab 2005;23:147-51.

18. Harris SS, Soteriades E, Coolidge JA, Mudgal S, Dawson-Hughes B. Vitamin D insufficiency and hyperparathyroidism in a low income, multiracial, elderly population. $\mathrm{J}$ Clin Endocrinol Metab 2000;85:4125-30.
19. Liu BA, Gordon M, Labranche JM, Murray TM, Vieth R, Shear NH. Seasonal prevalence of vitamin D deficiency in institutionalized older adults. J Am Geriatr Soc 1997;45:598-603.

20. Chel VG, Ooms ME, Popp-Snijders C, Pavel S, Schothorst AA, Meulemans CC, et al. Ultraviolet irradiation corrects vitamin D deficiency and suppresses secondary hyperparathyroidism in the elderly. J Bone Miner Res 1998;13:1238-42.

21. Holick MF, Matsuoka LY, Wortsman J. Age, vitamin D, and solar ultraviolet. Lancet 1989;2:1104-5.

22. Reginster JY, Deroisy R, Pirenne H, Frederick I, Dewe W, Albert A, et al. High prevalence of low femoral bone mineral density in elderly women living in nursing homes or community-dwelling: a plausible role of increased parathyroid hormone secretion. Osteoporos Int 1999;9:121-8.

23. Haden ST, Brown EM, Hurwitz S, Scott J, El-Hajj Fuleihan G. The effects of age and gender on parathyroid hormone dynamics. Clin Endocrinol (Oxf) 2000;52:329-38.

24. Serhan E, Newton P, Ali HA, Walford S, Singh BM. Prevalence of hypovitaminosis D in Indo-Asian patients attending a rheumatology clinic. Bone 1999;25:609-11.

25. Sahota O, Mundey MK, San P, Godber IM, Lawson $\mathrm{N}$, Hosking DJ. The relationship between vitamin D and parathyroid hormone: calcium homeostasis, bone turnover, and bone mineral density in postmenopausal women with established osteoporosis. Bone 2004;35:312-9.

26. Arunabh S, Pollack S, Yeh J, Aloia JF. Body fat content and 25-hydroxyvitamin D levels in healthy women. J Clin Endocrinol Metab 2003;88:157-61.

27. Lips P, Chapuy MC, Dawson-Hughes B, Pols HA, Holick MF. An international comparison of serum 25-hydroxyvitamin D measurements. Osteoporos Int 1999;9:394-7.

28. Dawson-Hughes B, Heaney RP, Holick MF, Lips P, Meunier PJ, Vieth R. Estimates of optimal vitamin D status. Osteoporos Int 2005;16:713-6. 